\title{
Characterization of Protease Production Efficiency of Bacteria Present in the Poultry Farm Soil
}

\author{
Rashmi Parihar ${ }^{1}$, Sumit Kumar Dubey ${ }^{2}$ \\ ${ }^{1,2}$ Department of Microbiology, Govt. E. R. R. Postgraduate Science College, Bilaspur, Chhattisgarh, India
}

\begin{abstract}
Proteases are widely used in food processing industries for the partial digestion of protein present in food stuff. These proteases could potentially be used in the food processing industries for the partial digestion of proteinaceous food stuffs like meat tenderization and partial digestion of baby food. Present research work has been focused on the characterization of protease production efficiency of bacteria present in the soil of poultry farm of Bilaspur city. A total thirty bacterial strains were isolated from domestic poultry farm, Bilaspur $\left(22.09^{\circ} \mathrm{N} 82.15^{\circ} \mathrm{E}\right)$. Among thirty bacterial strains, the four bacterial strains were selected by qualitative screening on the basis of clear zone. Further all four bacterial strains were screened for their specific protease activity. The two significant protease producing bacterial strains viz. PDB-2 and PDB-24 were identified as Bacillus sp. PDB-2 and Bacillus sp. PDB-24 and they represented $91 \%$ similarity to Bacillus licheniformis and $94 \%$ similarity to Bacillus cereus respectively on the basis of morphological, physiological and biochemical characteristics. Specific Protease activity of Bacillus sp. PDB-2 and Bacillus sp. PDB-24 were observed $32.47 \pm 0.60$ and $28.92 \pm 0.58$ (umole $\mathrm{min}^{-1} \mathrm{mg}^{-1} \pm S D$ ) respectively under an un-optimized condition. Bacillus $\mathrm{sp}$. PDB-2 showed maximum specific protease activity and after optimization, the specific protease activity was found to be increased by $1.27-$ fold (from $32.47 \pm 0.60$ to $41.52 \pm 1.56 \mu \mathrm{mol} \mathrm{min} \mathrm{mg}^{-1} \pm \mathrm{SD}$ ) at $45^{\circ} \mathrm{C}(\mathrm{pH}-8.5)$ for 96 h. Bacterial-derived proteases having significant activity could potentially be used in the food processing industries for the partial digestion of protein complexes present in the edible food-stuffs to increase its digestibility inside the human body.
\end{abstract}

Keywords: Food processing industries, Meat tenderization, Poultry farm, Specific protease activity, Bacillus sp., Bacterial-derived proteases

\section{Introduction}

Proteases (EC 3.4) belong to hydrolases class of enzyme that performs proteolytic action to hydrolyze the peptide bonds of a polypeptide chain [1] and [2]. Proteases are classified into four group's viz., Serine proteases (EC 3.4.21), Cysteine proteases (EC 3.4.22), Aspartic proteases (EC 3.4.23) and Metallo-peptidases (EC 3.4.24) [3]. Proteases are produced by animals, plants, fungi, bacteria and viruses and have a potential application in food processing, pharmaceuticals and detergent industries [4]. Activities of the poultry animals and shedding of their high protein content feathers and nails make the soil rich in protein degrading microbial flora. In case of, large scale production of plants- and animals-derived proteases, a huge land requirement and more time are needed as compared to microbial-derived protease production. So, as an alternative now days, the microorganisms are getting attention for faster rate of enzyme production at lower cost. Moreover, the genetic engineering techniques can also be easily applied in microbial cells to improve the efficiency of enzyme production [5]. Thus, the present research work has been focused on the characterization of protease production efficiency of bacteria present in the soil of poultry farm for its application in food processing industries.

\section{Materials And Methods}

Sampling and Isolation of Bacteria

Soil samples were aseptically collected in sterile poly bags from the domestic poultry farm, Bilaspur $\left(22.09^{\circ} \mathrm{N} 82.15^{\circ} \mathrm{E}\right)$ and brought to the laboratory. Bacterial strains were isolated in the Luria-Bertani (LB) agar media containing ( $/ \mathrm{v} ; \mathrm{g} \mathrm{l}^{-1}$ ) 10.0-peptone, 5.0 -yeast extract and $5.0-\mathrm{NaCl}$ in double distilled water $(\mathrm{pH}-7.0)$. The pure cultures of bacterial strains were prepared and stored at $4^{0} \mathrm{C}$ until used.
Qualitative Screening of Protease Producing Bacterial Strains

Skim-milk Agar Media (SAM) consisting of (w/v; $\left.\mathrm{g} \mathrm{l}^{-1}\right)$ 5.0yeast extract, $0.50-\mathrm{MgSO}_{4}, 0.25-\mathrm{KH}_{2} \mathrm{PO}_{4}$ and 20.0 -Skim milk powder in double distilled water $(\mathrm{pH}-7.0)$ was used for the qualitative screening of protease activity of each bacterial strain. The SAM plates were inoculated with a loop full pure culture of each test bacterial strain and incubated at $37^{\circ} \mathrm{C}$ for $48 \mathrm{~h}$ and thereafter, observed for clear zones around the bacterial colonies. The clear zones indicated the positive result for protease production by test bacterial strains.

\section{Protease Production}

Bacterial strains, those showed the positive protease activities in qualitative analysis were selected for the further assessment of protease production. Protease was produced by submerged fermentation process as per suggested by Anstrup [6] with some modification. $5.0 \mathrm{ml}$ of overnight bacterial culture $\left(5.7 \times 10^{6} \mathrm{CFU} \mathrm{ml}^{-1}\right)$ was added to the 100 $\mathrm{ml}$ of production media which consisted of $\left(\mathrm{w} / \mathrm{v} ; \mathrm{g}^{-1}\right) 5.0$ Peptone, 5.0-yeast extract, $0.50-\mathrm{MgSO}_{4}, 0.25-\mathrm{NH}_{4} \mathrm{SO}_{4}, 0.25$ $\mathrm{KH}_{2} \mathrm{PO}_{4}$ and $0.2-\mathrm{CaCl}_{2}$ in double distilled water (at $\mathrm{pH}-7.0$ ). Production media was supplemented with $2 \%$ skim milk as substrate and incubated in a rotary shaker-incubator at $37^{\circ} \mathrm{C}$ (120 rpm) for $72 \mathrm{~h}$. After incubation the fermented broth was centrifuged at $5000 \mathrm{rpm}$ for $20 \mathrm{~min}$ to remove bacterial cells from the fermented broth. After centrifugation, the clear supernatant was used as the source of crude protease.

\section{Partial Purification of Crude Protease}

Partial purification of crude protease was done by the method described by Zambare [7]. Crude protease was precipitated with ammonium sulphate (at $70 \%$ saturation) and centrifuged at $5000 \mathrm{rpm}$ for $20 \mathrm{~min}$ at $4^{0} \mathrm{C}$. After centrifugation, the crude protease precipitate was collected and dissolved in a $0.05 \mathrm{~mol} \mathrm{l}^{-1}$ Tris- $\mathrm{HCl}$ buffer $(\mathrm{pH} \mathrm{8.0)}$. 


\section{International Journal of Science and Research (IJSR) \\ ISSN (Online): 2319-7064}

Index Copernicus Value (2015): 78.96 | Impact Factor (2015): 6.391

This protease precipitate was loaded in a dialysis bag for dialysis and then dipped in beaker containing $100 \mathrm{ml}$ of $0.025 \mathrm{M}$ phosphate buffer and for $24 \mathrm{~h}$ on a magnetic stirrer for salting out. After dialysis the partially purified protease was collected and its activity was determined.

\section{Protein Estimation}

Protein estimation was done by the standard protocol of Lowery's method [8] using Bovine serum albumin as standard.

\section{Protease Assay}

Protease assay was done as suggested by Manivannan and Kathiresan [9], with some modification. $0.5 \mathrm{ml}$ of crude enzyme was incubated with $1.0 \mathrm{ml}$ casein solution $(2.0 \%$ casein in $0.1 \mathrm{M}$ Tris $\mathrm{HCl}$ buffer, $\mathrm{pH} 7.0$ ) for $10 \mathrm{~min}$ at $37^{\circ} \mathrm{C}$. The reaction was stopped by the addition of $5.0 \mathrm{ml}$ of $5 \%$ Trichloroacetic acid (TCA) and incubated for $30 \mathrm{~min}$. The mixture was filtered and added $4.0 \mathrm{ml}$ of $0.1 \mathrm{~N} \mathrm{NaOH}$ and $0.5 \mathrm{ml}$ Folin-Ciocalteau reagent and incubated for $30 \mathrm{~min}$. The amount of tyrosine released was measured colorimetrically at $670 \mathrm{~nm}$.

\section{Effect of pH, Temperature and Time}

The effect of $\mathrm{pH}(6.0$ to 9.0$)$, temperature $\left(30\right.$ to $\left.60^{\circ} \mathrm{C}\right)$ and time of incubation (24 to $120 \mathrm{~h}$ ) on enzyme activity were analyzed.

\section{Identification of Bacterial Strain}

The morphological, physiological and biochemical characteristics of significant protease producing bacterial strains were determined by Bergey's Manual of Determinative Bacteriology (BMDB) [10].

\section{Result And Discussion}

A total thirty bacterial strains were isolated from domestic poultry farm. Qualitative and quantitative screenings were performed for the assessment of protease production efficiency of bacterial strains. Among thirty bacterial strains, the four bacterial strains (PDB-2, PDB-7, PDB-24 and PDB29), on the basis of clear zone (Fig. 4) were selected for qualitative screening. PDB-2, PDB-7, PDB-24 and PDB-29 showed 15.2, 11.65, 18.47 and $6.79(\mathrm{~mm})$ clear zone around bacterial colony respectively. Further all four bacterial strains were screened for their specific protease activity. PDB-2, PDB-7, PDB-24 and PDB-29 showed $32.47 \pm 0.60$, $18.65 \pm 1.02,28.92 \pm 1.56$ and $9.24 \pm 0.89$ (specific protease activity $\mu$ mole $\mathrm{min}^{-1} \mathrm{mg}^{-1} \pm \mathrm{SD}$ ) respectively under an unoptimized condition. The crude protease was partially purified by ammonium sulphate precipitation method before the determination of its enzyme activity.

Two bacterial strains PDB-2 and PDB-24 were morphologically, physiologically and biochemically characterized by the method described in BMDB [10]. Results showed that both bacterial strains, PDB-2 and PDB24 belong to Bacillus sps. and identified as Bacillus sp. PDB-2 and Bacillus sp. PDB-24 and represented 91\% similarity to Bacillus licheniformis and $94 \%$ similarity to Bacillus cereus respectively as per their morphological, physiological and biochemical characteristics as described in BMDB. B. cereus CA15 [11], B. licheniformis [12] and [13],
B. licheniformis UV-9 Mutant [14], Bacillus sp. NKS21[15], Bacillus sp. Y [16], Bacillus sp. CW-1121 [17] and Bacillus sp. KSM-K16 [18] have been reported earlier for significant protease production.

During screening of potential bacterial strains, it was noted that PDB- 24 showed maximum protease activity in terms of clear zone during qualitative analysis (Fig. 4) but later in quantitative analysis PDB- 2 exhibited maximum specific protease activity. This may be due to the different conditions used in each technique; means, in quantitative screening experimental flasks were incubated inside shaker at $120 \mathrm{rpm}$ for $72 \mathrm{~h}$, whereas in qualitative screening the plates were incubated inside incubator at $37^{\circ} \mathrm{C}$ for $48 \mathrm{~h}$. Also it may possible that for PDB-2, the incubation period and shaking were significant parameters for protease production. Due to maximum specific protease activity yield $(32.47 \pm 0.60 \mu \mathrm{mol}$ $\mathrm{min}^{-1} \mathrm{mg}^{-1} \pm \mathrm{SD}$ ) obtained with PDB-2 under an unoptimized system, so this strain was further selected for optimization to enhance its specific protease activity. During the optimization, the $\mathrm{pH}$ range, from 6.0 to 9.0 was analyzed and the maximum specific protease activity $(38.60 \mu \mathrm{mol}$ $\mathrm{min}^{-1} \mathrm{mg}^{-1}$ ) was obtained at $\mathrm{pH}-8.5$ (at constant temperature$37^{\circ} \mathrm{C}$ and time- $72 \mathrm{~h}$ ). After increasing the $\mathrm{pH}$ from 8.5 to 9.0, the reduction in specific protease activity (from 38.60 to $36.24 \mu \mathrm{mol} \mathrm{min} \mathrm{mg}^{-1}$ ) was observed (Table 1 and Fig. 1). This finding indicates that the protease produced was slightly alkaline in nature. Seenivasagham and Rose reported the maximum protease activity at $\mathrm{pH} 8.0 \quad\left(37^{\circ} \mathrm{C}\right)$ [19]. Zambare worked on protease production by Pseudomonas aeruginosa MCM B-327 and found the optimum $\mathrm{pH}$ of 8.0 [7].

The temperature range was (from 30 to $50^{\circ} \mathrm{C}$ ) and the maximum specific protease activity was recorded at $45^{\circ} \mathrm{C}$

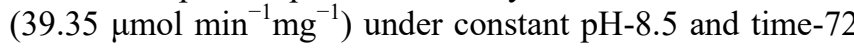
h (Table 1 and Fig. 2) and after increasing the temperature from 45 to $50^{\circ} \mathrm{C}$, the specific protease activity was getting down to $37.21 \mu \mathrm{mol} \mathrm{min} \mathrm{mg}^{-1}$. This may be due to the inhibition of enzyme by temperature. Further the time at a range of 24 to $120 \mathrm{~h}$ was assessed. Results showed that, the maximum specific protease activity was found at $96 \mathrm{~h}(41.52$ $\mu \mathrm{mol} \mathrm{min} \mathrm{mg}^{-1}$ ) and further acceleration in temperature from 96 to $120 \mathrm{~h}$, the specific activity was dropped from 41.52 to $38.57 \mu \mathrm{mol} \mathrm{min} \mathrm{mg}^{-1}$ (Table 1 and Fig. 2). After optimization, the specific protease activity of Bacillus $s p$. PDB- 2 was found to be increased by 1.27 -fold (from 32.47

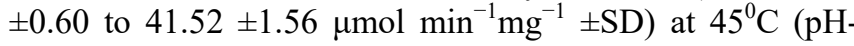
8.5) for $96 \mathrm{~h}$ (Table 1).

\section{Conclusion}

The present research work was done to reveal the protease production efficiency of bacterial strains present in the domestic poultry farm. The bacterial strains, Bacillus sp. PDB-2 and Bacillus sp. PDB-24 were identified for significant protease production. Afterward, Bacillus sp. PDB-2 was optimized and specific protease activity was increased by 1.27 -fold under optimized condition. This protease enzyme could potentially be used in the food processing industries for the partial digestion of proteinaceous food stuffs. The partial digestion of proteinaceous food makes it easily digestible inside the

\section{Volume 6 Issue 1, January 2017




\section{International Journal of Science and Research (IJSR) \\ ISSN (Online): 2319-7064}

Index Copernicus Value (2015): 78.96 | Impact Factor (2015): 6.391

human stomach. Further, the study of protease production by make it cost effective.

Bacillus sp. PDB-2 using cheaper substrate is on way to

Table 1: Specific Protease Activity of Bacillus sp. PDB-2 at Different Parameters

\begin{tabular}{|c|c|c|c|c|c|c|}
\hline Un-optimized System & \multicolumn{6}{|c|}{ Optimized System } \\
\hline $\begin{array}{l}\text { Specific protease activity } \\
\left(\mu \mathrm{mole} \mathrm{min}^{-1} \mathrm{mg}^{-1} \pm S D\right)\end{array}$ & $p H$ & $\begin{array}{l}\text { Specific protease activity } \\
\left(\mu \mathrm{mole} \mathrm{min}^{-1} \mathrm{mg}^{-1} \pm S D\right)^{1}\end{array}$ & Temperature & $\begin{array}{l}\text { Specific protease activity } \\
\left(\mu \mathrm{mole} \mathrm{min}^{-1} \mathrm{mg}^{-1} \pm S D\right)^{2}\end{array}$ & Time & $\begin{array}{l}\text { Specific protease activity } \\
\left(\mu \mathrm{mole} \mathrm{min}^{-1} \mathrm{mg}^{-1} \pm S D\right)^{3}\end{array}$ \\
\hline \multirow{7}{*}{$32.47 \pm 0.60$} & 6.0 & $18.31 \pm 0.86$ & 30 & $22.47 \pm 0.68$ & 24 & $13.98 \pm 1.46$ \\
\hline & 6.5 & $23.49 \pm 1.14$ & 35 & $28.64 \pm 1.27$ & 48 & $21.67 \pm 0.91$ \\
\hline & 7.0 & $26.78 \pm 0.95$ & 40 & $35.41 \pm 1.34$ & 72 & $39.33 \pm 0.82$ \\
\hline & 7.5 & $31.47 \pm 0.84$ & 45 & $39.35 \pm 1.29$ & 96 & $41.52 \pm 1.56$ \\
\hline & 8.0 & $34.50 \pm 1.04$ & 50 & $37.21 \pm 1.15$ & 120 & $38.57 \pm 1.43$ \\
\hline & 8.5 & $38.60 \pm 0.97$ & & & & \\
\hline & 9.0 & $36.24 \pm 0.71$ & & & & \\
\hline
\end{tabular}

Un-optimized System - $\mathrm{pH}-7.0$, Temperature $-37{ }^{\circ} \mathrm{C}$ and Time $-72 \mathrm{~h}$ were constant

Optimized System - $\quad{ }^{1} \mathrm{pH}$ varied while Temperature $\left(37^{\circ} \mathrm{C}\right)$ and Time $(72 \mathrm{~h})$ were constant

${ }^{2}$ Temperature varied while $\mathrm{pH}(8.5)$ and Time $(72 \mathrm{~h})$ were constant

${ }^{3}$ Time varied while $\mathrm{pH}(8.5)$ and Temperature $\left(45^{\circ} \mathrm{C}\right)$ were constant

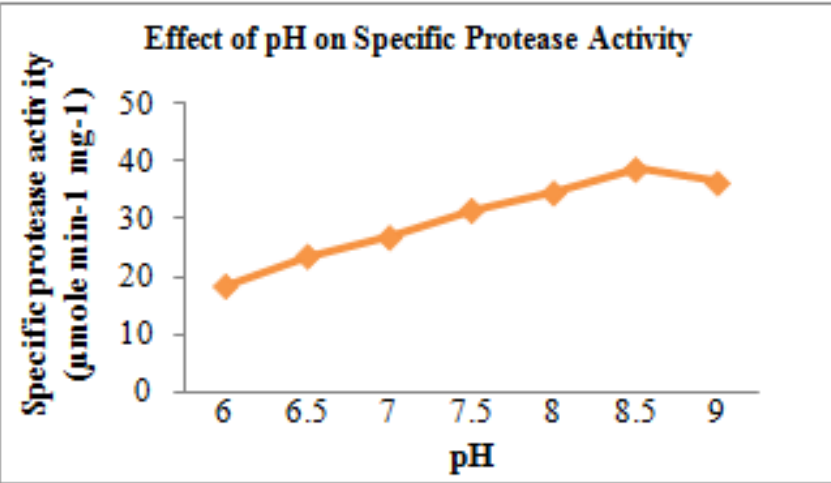

Figure 1: Effect of $\mathrm{pH}$ on Specific Protease Activity

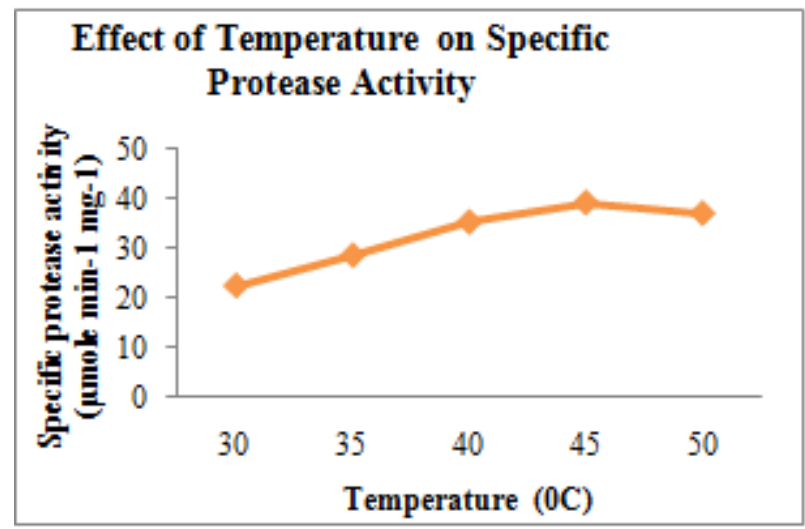

Figure 2: Effect of Temperature on Specific Protease Activity

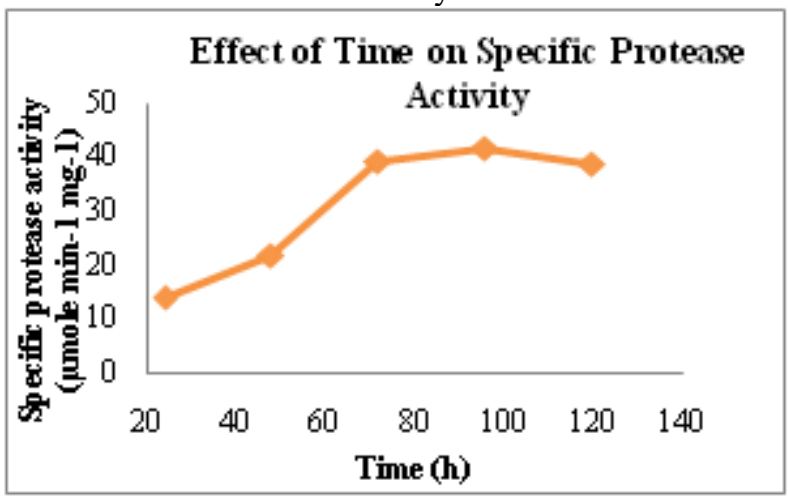

Figure 3: Effect of Time on Specific Protease Activity

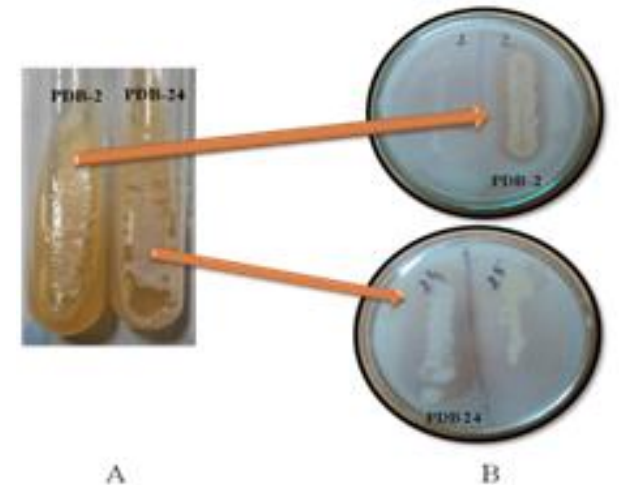

Figure 4: Quantitatively screened bacterial strains (PDB-2 and PDB-24) (A) Agar slants (B) Clear zones in SAM plates

\section{Acknowledgement}

The authors would like to give vote of thanks to Principal, Govt. E. R. R. Postgraduate Science College, Bilaspur (C.G.) for providing well equipped lab facility to work.

\section{References}

[1] Godfrey T. and Reichet P. (1985). Industrial Enzymology: The Applications of Enzymes on Industry. The Nature Press, London.

[2] Hooper, ed. by N. M. (2002). Proteases in biology and medicine. London: Portland Press. ISBN 1-85578-1476.

[3] Hartley B.S. (1960) Proteolytic enzymes. Annual Review of Biochemistry, 29, 45-72

[4] Gupta R., Beg Q.K. and Lorenz P. (2002) Bacterial alkaline proteases: molecular approaches and industrial application. App Microbiol Biotechnol, 59: 15-32.

[5] Godfrey T. and West S. (1996) Introduction to industrial enzymology. Industrial enzymology, Mac. Millan Press, London, 1-8.

[6] Anstrup K. (1974) Industrial production of proteolytic enzymes. In Spencer (ed): Industrial Aspects of Biochemistry, vol. 30, Part 1 B Amsterdam: North Holland Publication Co. 


\section{International Journal of Science and Research (IJSR) \\ ISSN (Online): 2319-7064 \\ Index Copernicus Value (2015): 78.96 | Impact Factor (2015): 6.391}

[7] Zambare V.P., Nilegaonkar S.S., Kshirsagar P.R. and Kanekar P.P. (2014) Scale up production of Protease using Pseudomonas aeruginosa MCM B-327 and its Detergent Compatibility. J Biochem Tech, 5(2): 698707.

[8] Lowry O.H., Rosebrough N.J., Farr A.L. and Randall R.J. (1951) Protein measurement with the folin-phenol reagent. J Biol Chem, 193: 265-275.

[9] Manivannan S. and Kathiresan K. (2007). Alkaline Protease Production by Penicillium fellutanum Straind from Mangrove Sediment. International Journal of Biological Chemistry, 1: 98-103

[10] Holt J.G., Krieg N.R., P.H.A. Sneath Stately J.T. and Williams ST. (2004) Bergey's manual of determinative bacteriology. $9^{\text {th }}$ ed., Baltimore. Williams and Wilkins: 787.

[11]Uyar F., PorsukI Kizil G. and Yilmaz E.I. (2011) Optimal conditions for production of extracellular protease from newly strain Bacillus cereus strain CA15. Eur Asia J BioSci. 5, 1-9. doi:10.5053/ejobios.2011.5.0.1.

[12] Ageitos J.M., Vallejo J.A. and Sestelo A.B.F. (2007) Purification and characterization of a milk-clotting protease from Bacillus licheniformis strain USC13. Journal of Applied Microbiology, 103, 2205-2213. doi:10.1111/j.1365-2672.2007.03460.x

[13] Abuoul E.H., Enein A., Helmy S. and Azaly Y. (2008) Optimization of the industrial production of alkaline protease by Bacillus licheniformis in different production scales. Australian Journal of Basic and Applied Sciences, 2, 583-593.

[14] Nadeem M., Qazi J.I., Iqbal J. and Baig S. (2009) Effect of aeration and agitation rates on alkaline protease production by Bacillus licheniformis UV-9 mutant. Turkish Journal of Biochemistry, 34, 89-96.

[15] Takagi H., Kondou M., Hisatsuka T., Nakamori S., Tsai Y.C. and Yamasaki M. (1992) Effects of an alkaline elastase from an alkalophilic Bacillus strain on the tenderiza- tion of beef meat. Journal of Agricultural and Food Chemistry, 40, 2364-2368. doi:10.1021/jf00024a008

[16] Shimogaki H., Takeuchi K., Nishino T., Ohdera M., Kudo T., Ohba K., Iwama M. and Irie M. (1991) Purification and properties of a novel surface-active agent and alkaline-resistant protease from Bacillus $s p$. Agricultural and Biological Chemistry, 55, 2251-2258. doi:10.1271/bbb1961.55.2251

[17] Lee W.J., Son G.M. and Choi C. (1991) Production and purification of alkaline protease from Bacillus sp. CW1121. Journal of the Korean Society of Food Science and Nutrition, 20, 388-394.

[18] Kobayashi T., Hakamada Y., Adachi S., Hitomi J., Yoshimatsu T., Koike K., Kawai S. and Ito S. (1995) Purification and properties of an alkaline protease from alkalophilic Bacillus sp. KSM-K16. Applied Microbiology and Biotechnology, 43, 473-481. doi:10.1007/BF00218452

[19] Seenivasagham V.D. and Rose C. (2016) Studies on optimization of protease production using bacterial isolate CLRI strain 5468 and its application in dehairing and hydrolysis of tannery fleshings (solid waste management). International Journal of Scientific \& Technology Research, 5 (03). ISSN 2277-861.

\section{Author Profile}

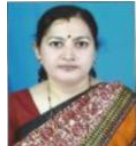

Dr. Rashmi Parihar is Assistant Professor, Department of Microbiology, Govt. E. R. R. Postgraduate Science College, Bilaspur (C.G.)

Sumit Kumar Dubey is Research Scholar, Department of Microbiology, Govt. E. R. R. Postgraduate Science College, Bilaspur (C.G.) 